\title{
Tulane
}

Tulane Economics Working Paper Series

\section{A Peculiar Sample: a reply to Steckel and Ziebarth}

\author{
Jonathan Pritchett \\ Department of Economics \\ Tulane University \\ jprit@tulane.edu
}

\author{
Herman Freudenberger \\ Department of Economics \\ Tulane University \\ hfreude@tulane.edu
}

Working Paper 1504

May 2015

\begin{abstract}
Steckel and Ziebarth (2014) find that biases in height by age imposed by traders versus non-traders were negligible. Importantly, their method of identifying traders differs from that of Pritchett and Freudenberger (1992). Using a sample of inward coastwise manifests for the port of New Orleans, we show that Steckel and Ziebarth made errors classifying shippers, that they underestimate the relative number of slaves shipped by traders, and that their empirical estimates of selection bias are attenuated towards zero.
\end{abstract}




\title{
A Peculiar Sample: a reply to
}

\section{Steckel and Ziebarth}

\author{
Jonathan Pritchett and Herman Freudenberger*
}

May 2015

\begin{abstract}
Steckel and Ziebarth (2014) find that biases in height by age imposed by traders versus non-traders were negligible. Importantly, their method of identifying traders differs from that of Pritchett and Freudenberger (1992). Using a sample of inward coastwise manifests for the port of New Orleans, we show that Steckel and Ziebarth made errors classifying shippers, that they underestimate the relative number of slaves shipped by traders, and that their empirical estimates of selection bias are attenuated towards zero.
\end{abstract}

* Pritchett is Associate Professor of Economics, Tulane University; e-mail address: jprit@tulane.edu; Freudenberger is Professor Emeritus of Economics, Tulane University; e-mail address: hfreude@tulane.edu. The authors benefited from the helpful comments and suggestions of James Alm, Stanley Engerman, and Timothy Guinnane. 
Interregional traders preferred to traffic in higher valued slaves (Pritchett and Freudenberger 1992). The basis of our argument is the so-called Alchian and Allen theorem -- when a fixed transport cost is applied to two goods of varying quality, the relative price of the higher quality good is lower in the distant market. Because quantity demanded is inversely related to relative price, buyers in distant markets prefer to purchase relatively more of the higher quality good. This theory has a number of important implications regarding the type of slaves sold by traders. ${ }^{1}$ Most importantly, theory suggests that the slaves chosen by traders were not a random sample of the local population and possessed observable characteristics that enhanced their market values.

Because taller slaves commanded higher market prices (Margo and Steckel 1982), we predict that traders chose taller slaves for shipment to distant markets. The effects of selection on the heights of slaves should be greatest for children because they experienced the largest increase in relative price (Pritchett 1997, p. 73). Pritchett and Freudenberger (1992) test these propositions by comparing the heights of slaves owned by traders and those owned by others. We limited our analysis to the inward coastwise manifests for New Orleans, a major slave market and the primary destination for slaves shipped within the United States (Steckel and Ziebarth 2013, p. 803). Presumably other shippers and

\footnotetext{
${ }_{1}^{1}$ Prime-aged males commanded higher market prices in New Orleans than other slaves (Kotlikoff 1979, p. 501). Consistent with Alchian and Allen's theorem, Fogel and Engerman (1974, p. 53) find that interregional traders preferred to ship males rather than females. Compared to planter migrations, Michael Tadman (1979, p. 200; 1989) finds that interregional traders were highly age selective, shipping slaves in the twelve to twenty-five age range. In addition, see evidence presented by Pritchett (1997, pp. 66-71). Because transport cost increases with distance to market, Alchian and Allen's theory also predicts that the average prices of slaves and the relative number of prime-aged slaves should be positively correlated with distance (Greenwald and Glasspiegel 1983; Pritchett and Chamberlain 1993). During periods of high slave prices, traders were less selective in their shipments, resulting in relatively more children and older adults among the slaves. Freudenberger and Pritchett $(1991$, p. 458) find that the relative number of prime-aged slaves varies inversely with slave prices. Consistent with the theorem, Pritchett $(1997$, p. 66) estimates higher relative prices for children sold in New Orleans. More recently, Choo and Eid $(2008$, p. 500) test Alchian and Allen's theory using evidence from slave sales in New Orleans. Because males commanded higher prices than females, Alchian and Allen's theory predicts that relatively more males should have been shipped from distance. They found the opposite and as a consequence, rejected the theory. The authors, however, made a math error and should have accepted the theory. See http://www.jeaneid.org/paragraph_6.2correction.pdf
} 
especially migrating planters were less selective than slave traders and shipped slaves of all types. ${ }^{2}$ We classified a shipper as a slave trader if he sold slaves in New Orleans during the year of shipment. Using this method of identification, we find that interregional slave traders chose taller slaves for shipment to New Orleans and that the effects of selection were greatest for children and adolescents.

Traders accounted for a significant share of the slaves shipped coastwise during the antebellum period. If traders selected taller slaves, then the age/height profiles constructed from coastwise manifests will be bias upwards. Furthermore, the bias may vary across covariates of interest, such as time, space, age and gender. Distorted age/height profiles would affect our understanding of the anthropometrics of slavery, including such issues as the age of menarche, health conditions (including the infant mortality rate), the cost/benefit analysis of slave diets, and spatial and temporal variation in the net nutritional status of slaves. ${ }^{3}$ Because selection bias may also affect samples drawn from other populations, evidence of selective shipments by slave traders has been met with renewed interest by economic historians (Bodenhorn, Guinnane, and Mroz 2013; 2014). Sample selection bias may also affect the estimated market prices of slaves. If traders preferred to deal in higher-valued slaves, then the relationship between slave prices and observables may be endogenous (e.g., Kotlikoff 1979, 1992; Levendis 2007; Choo and Eid 2008). Finally, slaveholders sometimes found it profitable to keep families together (Fogel and Engerman 1974; Calomiris and Pritchett 2009). Selective purchases by traders would pull families apart. By the trader's calculation, only some slaves were eligible for purchase and shipment to the west. Selective purchases by traders threatened the family bonds between those eligible for shipment and those who were not.

\footnotetext{
${ }^{2}$ On the non-selective nature of planter migrations, see Pritchett and Freudenberger (1992, p. 112).

${ }^{3}$ See Pritchett and Freudenberger (1992, p. 109) for citations.
} 
In a recent paper, Richard Steckel and Nicolas Ziebarth (2015, p. 4) find that slaves shipped by traders were not taller than those shipped by others and that age/height profiles constructed from coastwise manifests do not exhibit an upward bias. Importantly, these authors use a different method for identifying the manifests of slave traders. In this paper, we argue that their identification method is flawed and their empirical estimates are attenuated towards zero. We show that traders chose taller slaves for shipment to New Orleans and as a consequence, the age-height profiles calculated from the coastwise manifests are biased upwards.

\section{Identifying traders}

Our disagreement with Steckel and Ziebarth concerns the classification of manifests belonging to slave traders. The occupations of shippers were not recorded on the manifests and in nearly every case, we infer this information from other sources. Using their methodology for identifying traders, Steckel and Ziebarth find no evidence of traders choosing taller slaves whereas using our methodology, we find such evidence. In the following, we review the different methodologies used by Pritchett and Freudenberger (1992) and Steckel and Ziebarth (2015) and discuss possible sources of classification error.

Pritchett and Freudenberger (1992, p. 115) identified slave traders by comparing the names of owners with those of slave sellers listed in the New Orleans Conveyance records. ${ }^{4}$ Those shippers who sold slaves in New Orleans during the year of shipment were classified as slave traders and all other shippers were classified as non-traders. We believe this classification scheme has much in common with

\footnotetext{
${ }^{4}$ The conveyance records are comprehensive, indexed by seller's name, and their coverage begins in 1827. Because Steckel did not record the first name of shippers, we consulted the original manifests to obtain this information. We recorded first names to insure accurate matches and to minimize errors in classifying manifests. We also recorded the names of slave owners (if they differed from those of the shippers) and checked for coding errors. For those manifests that list both shipper and owner, we used the owner's name to establish trading status.
} 
accepted definitions of the slave trade. ${ }^{5}$ In particular, we defined slave traders as shippers who traded slaves. We recognize, however, that our classification scheme is imperfect. Some traders may have transshipped slaves through New Orleans without selling any of them. In addition, some first time sellers may have been best classified as migrating planters rather than interregional traders.

Steckel and Ziebarth's classification scheme is more complex and presumably subject to greater measurement error than ours. They identify traders by comparing the surnames of shippers with those of traders as identified by Bancroft (1931) or Tadman (1989), and with those of slave traders listed in newspaper advertisements. Shippers with surnames and ports of departure that appeared five or more times in their sample were also classified as traders. They surmise that the vast majority of these frequent shippers were traders (Steckel and Ziebarth 2013, p. 802).

Because comprehensive lists of slave sellers do not exist for other ports, Steckel and Ziebarth do not use our method for classifying manifests. As we will show, their classification scheme is subject to greater measurement error than ours and their empirical results are attenuated towards zero.

\section{Comparing classification schemes}

In Table 1, we cross tabulate the sample to illustrate the different classifications of the manifests. Per our request, Steckel and Ziebarth provided us with a list of manifests they attribute to the shipments of slave traders. Because they did not classify some manifests, our working sample is a subset of the original sample and includes the records of 457 manifests and a total of 5,885 slaves. Steckel and Ziebarth identify 181 manifests listing 3446 slaves as belonging to slave traders. These records comprise 40 percent of the manifests and 59 percent of the slaves in the working sample. Using

\footnotetext{
${ }^{5}$ The Oxford American College Dictionary (2002) defines the slave trade as "the procuring, transporting, and selling of human beings as slaves, in particular the former trade in African blacks as slaves by European countries and North America." Webster's New World Dictionary (1984) defines the slave trade as "traffic in slaves; specif., the former transportation of African Negroes to America for sale as slaves."
} 
our classification method, we identified 140 manifests listing 4231 slaves as belonging to slave traders. We find that 31 percent of manifests and 72 percent of the slaves were shipped by traders. Compared with their classification method, our method assigns fewer manifests and relatively more slaves to the shipments of slave traders.

We find meaningful differences in the classifications of these manifests and slaves. Overall, we agree on the ownership of 64 percent of the slaves. Although the classifications are positively correlated, they are not strongly correlated $(\rho=0.25)$. As we will show, the different classification schemes account for the different empirical results reported by Steckel and Ziebarth (2015) and ourselves.

Presumably, the number and types of slaves shipped by traders were influenced by a desire for profit. Consider, for example, the average number of slaves per voyage. If marketing and supervisory costs did not rise in proportion to shipment size, traders likely found it profitable to ship larger cargoes. Rather than the shipments of traders, smaller manifests probably reflect the short-term movements of servants with owners or represent the crews of ships (Tadman 1989, p. 61; Margo and Steckel 1982, p. 520). Indeed, using our classification, the average number of slaves per shipment was 6.3 for nontraders and 32.5 for traders. Using Steckel and Ziebarth's classification, the average shipment was 9.9 slaves for non-traders and 21.1 slaves for traders. For these authors, manifest size "variedly widely for traders and non-traders" (Steckel and Ziebarth 2013, p. 803). In summary, both sets of authors find that traders shipped more slaves per voyage than did non-traders and the difference in manifest size is larger using our classification method than it is using theirs.

Alchian and Allen's theory implies that traders would select higher valued slaves for shipment. Because prime-aged slaves commanded higher prices, we predict that traders would select relatively more prime-aged slaves than other shippers. Evidence supporting this prediction is mixed and depends 
on the method for classifying manifests. The trader's preference for prime-aged slaves (aged 10 to 30 years) is evident using our classification method. Prime-aged slaves comprised 85.4 percent of the slaves shipped by traders and only 65.3 percent of the slaves shipped by non-traders, a statistically significant difference of 20.1 percentage points. For Steckel and Ziebarth, the trader's preference for prime-aged slaves is much less evident. Using their method, prime-aged slaves comprise 82.2 percent of the slaves shipped by traders and 75.6 percent for those shipped by non-traders, a difference of only 6.6 percentage points. The large percentage of prime-aged slaves attributed to non-traders is especially surprising considering the non-selective character of planter migrations (Tadman 1989, p. 235). Consequently, evidence of selective shipments by traders is largely dependent on the choice of classification method.

Different classification schemes result in different descriptive statistics for the manifests of traders and non-traders. We seek to resolve these differences by comparing the subset of manifests where both sets of authors agree to the classification. As seen in Table 1, both set of authors attribute 221 manifests to non-traders (as indicated by group A) and 85 manifests to traders (as indicated by group D). The average number of slaves per shipment was 5.4 for non-traders (group A) and 35.6 for traders (group D). Prime-aged slaves (aged 10 to 30 years) comprise 62.6 percent of the slaves shipped by consensus non-traders (group A) and 85.4 percent of the slaves shipped by consensus traders (group D), a statistically significant difference of 22.8 percentage points. Consequently, for those slaves where both sets of authors agree as to ownership, traders had larger cargoes and preferred to ship prime-aged slaves.

Descriptive statistics presented in Table 1 provide indirect evidence of classification errors made by Steckel and Ziebarth. The difference in our empirical results and ultimately the source of our disagreement regarding the selective character of the slave trade lies in those observations where we 
disagree about the trading status of the shipper (as represented by groups B and C in Table 1). If Steckel and Ziebarth correctly identified the owners of these slaves, then larger cargoes and relatively more prime-aged slaves should be found in group B (manifests belonging to slave traders) than in group C (manifests belonging to other shippers). In contrast, if we are correct, then we should find the opposite result. Indeed, we find larger cargoes and relatively more prime-aged slaves in group C, who we classified as belonging to slave traders. The average shipment size was 27.7 slaves in group $\mathrm{C}$ and only 8.1 slaves in group B, a statistically significant difference of 19.6 slaves. Prime-aged slaves comprise 85.5 percent of the slaves in group $\mathrm{C}$ and 69.6 percent of the slaves in group $\mathrm{B}$, a statistically significant difference of nearly 16 percentage points. The fact that larger cargoes and relatively more prime-aged slaves are found in group C than in group B suggests that Steckel and Ziebarth misclassified these manifests.

In our 1992 article, we compared the average heights of slaves shipped by traders with those of slaves shipped by non-traders. We found that the mean heights of slaves shipped by traders were greater for 39 of 44 age/gender categories and that the difference was statistically significant for 23 of these categories (Pritchett and Freudenberger 1992, p. 116-117). Steckel and Ziebarth (2015, Tables 3 and 4) also compare the average heights of slaves by age, gender, and trader status. They, however, find no evidence that traders selected taller slaves. For westward shipments, they find that the mean heights of slaves shipped by traders were greater than those of slaves shipped by non-traders for (exactly) half of the age/gender categories (26 to 52) from which they conclude that "there is no important and systematic difference in heights by age for males or females" (Steckel and Ziebarth 2015, p. 12).

How do we resolve these conflicting empirical results? We again propose a comparison of those manifests where we both agree to the classifications. These manifests (represented by groups A and D 
in Table 1) record the shipment of 3792 slaves and represent 64 percent of the observations in our working sample. The comparison of the average height of slaves shipped by consensus traders and by consensus non-traders differs from our previous comparisons. In particular, the precision of our estimates and the statistical power of our t-tests are reduced because of the smaller sample size. As seen in Tables 2 and 3, the qualitative results are quite similar to those found in our earlier article (Pritchett and Freudenberger 1992, pp. 116-7). The mean heights of slaves shipped by traders were greater for 38 of 44 age/gender categories. One-sided t-tests indicate that the slaves shipped by traders were significantly taller for 17 of these age/gender categories. Because the height distributions for the two groups may differ, we also estimate nonparametric Wilcoxon-Mann-Whitney tests. These results indicate statistical significance for 17 age/gender categories. For this subset of our working sample, we find strong evidence that the slaves shipped by traders were taller than those shipped by others.

The difference in our empirical results and ultimately, the source of our disagreement with Steckel and Ziebarth, lies in those observations where we disagree about the trading status of the shipper (as indicated by groups B and C in Table 1). We contend that Steckel and Ziebarth misclassified these manifests. In the following, we present examples of classification errors made by these authors.

\section{Classification errors - errors of omission}

Consider those manifests that we attribute to slave traders and Steckel and Ziebarth attribute to non-traders. As indicated by group C in Table 1, the 1439 slaves in this group comprise approximately 24 percent of our working sample. Because Steckel and Ziebarth lack a comprehensive list of traders, their methodology results in some slave traders being misclassified as non-traders. Neither Bancroft nor Tadman published a complete list of slave traders. In addition, Steckel and Ziebarth did not consult 
other secondary sources that identified interregional slave traders. ${ }^{6}$ They did not examine all newspapers where traders placed their advertisements. ${ }^{7}$ Finally, not all traders advertised in newspapers. Because these sources omit the names of some traders, this classification scheme is subject to measurement error. In particular, we suspect that some shippers employed as slave traders were misclassified as non-traders.

Komlos and Alecke (1996, p. 452) criticized our classification scheme because some owners may have sold slaves without the use of an intermediary. In fact traders both purchased slaves in the exporting areas and subsequently resold them in New Orleans. In 1829, the Louisiana legislature passed a law requiring imported slaves be accompanied by a so-called Certificate of Good Character, attesting that the slave was of good moral character and not in the habit of running away (Freudenberger and Pritchett 1991). Because the certificate lists the former owner (and in many cases, the name of the buyer in the exporting area), this document in conjunction with the sales invoice provides information about the purchase by the trader and the subsequent resale in New Orleans. In Table A1, we list 15 traders misclassified as non-traders by Steckel and Ziebarth as indicated by sales information derived from the certificates of good character. ${ }^{8}$ Consider, for example, James Huie, a trader who resided in Salisbury, North Carolina and sold slaves in New Orleans. Huie purchased 80 slaves from 59 different sellers and drove the slaves overland to the port of Mobile, Alabama. For the final leg of the voyage, Huie shipped his slaves via packet steamer to New Orleans. Because Huie purchased slaves in the

\footnotetext{
${ }^{6}$ Examples of shippers identified as traders from other secondary sources (but not identified as such by Steckel and Ziebarth) are Seraphin Cuculla (Johnson 1999, p. 122), Leon Chabert (Phillips 1929, p. 156), and James Huie (Phillips 1929, p. 155).

${ }^{7}$ Robert Huie, another trader misclassified by Steckel and Ziebarth, advertised in Salisbury, NC that he wanted to purchase slaves. See Phillips (1929, p. 157).

${ }^{8}$ Table $A 1$ is found in the on-line appendix.
} 
exporting areas and then resold them in New Orleans, he is an example of a trader who is misclassified as a non-trader by Steckel and Ziebarth. ${ }^{9}$

\section{Classification errors - Matching shippers with slave traders}

In this section, we consider the non-traders who were misclassified as traders by Steckel and Ziebarth (this group of manifests and slaves is indicated by group B in Table 1). These manifests record the shipment of 654 slaves and represent approximately 11 percent of the working sample. Steckel began this project many years ago when data collection technology was rudimentary and data were transcribed on 80-column punch cards. Because of technology and resource constraints, Steckel dedicated only 12 columns to record the shipper's surname (Steckel and Ziebarth 2013, p. 802). This data limitation affects the accuracy of the matches and results in the misclassification of manifests.

When an owner traveled with his slaves, the shipper and the slave owner were the same person and the manifest lists only one responsible party. For approximately 18 percent of the manifests, however, the names of both the shipper and the owner are recorded. When faced with the choice of recording the surname of the shipper or that of the owner, Steckel chose to record the shipper's name. For the purposes of this project, this decision was a mistake. Owners hired shippers to transport their slaves. The owner, not the shipper, selected the slaves for shipment. Evidence of selection bias will be found by comparing the names of slave traders with those of owners, not those of shippers. Because they compared the names of shippers with those of traders, Steckel and Ziebarth misclassified those manifests that list both shipper and owner.

\footnotetext{
${ }^{9}$ Additional evidence of Huie's occupation is found in the New Orleans city archive (New Orleans City Archives, 1831). On 3 Nov. 1831, Huie arrived in New Orleans onboard the schooner Magnolia with 106 slaves from the port of Mobile. In a sworn affidavit, Huie declared that the slaves were introduced and "intended for sale in the City of New Orleans."
} 
When collecting these data, Steckel did not record the first names of shippers. Because of this omission, many of Steckel's matches are simply wrong. Steckel provided us with a list of manifests where the names of shippers were matched with those of traders. As seen in table A2, most shippers have different first names than those of identified slave traders. ${ }^{10}$ Of 28 possible matches, only three appear to be correct. Two other matches might be correct (because the secondary sources do not list the trader's first name). In other words, at least 80 percent of these manifests are misclassified, based on the matching procedure used by Steckel and Ziebarth. Because Steckel failed to collect pertinent information such as the first names of shippers, Steckel and Ziebarth misclassify the manifests of nontraders.

Steckel and Ziebarth classified shippers who made five or more voyages from the same port as slave traders. ${ }^{11}$ Using this method, some ship captains are misclassified as slave traders. Ship captains made frequent voyages and were occasionally listed as shippers of slaves. For our working sample, we find 24 manifests where the ship captain is also listed as the shipper of slaves. Using evidence of slave sales in New Orleans, only one of these captains can be classified as a slave trader. In contrast, Steckel and Ziebarth attribute 16 of these manifests (or two thirds) to slave traders. Consider, for example, J. E. Haviland, captain of the packet steamboat Galveston operating between the ports of Galveston and New Orleans. Steckel and Ziebarth incorrectly identify this ship captain as a trader because he made frequent voyages and because he shipped slaves (and not because he sold them).

\footnotetext{
${ }^{10}$ Table A2 may be found in the on-line appendix. Some shippers, especially those with common surnames, are matched multiple times to potential traders. In nearly every case, these identified slave traders had different first names than the shippers.

${ }^{11}$ Classifying shippers by frequency of voyages is also subject to error. Because some manifests are missing, the frequency of voyages is underestimated for some shippers. In addition, shippers with common surnames may be lumped together, causing an overestimate for the frequency of voyages.
} 


\section{Regression analysis}

In our 1992 article, we used regression analysis to estimate the effect of selective purchases by traders on the heights of slaves shipped coastwise. Rather than an indicator variable, we used an instrument for trading status to deal with the inconsistencies introduced by classification errors (Pritchett and Freudenberger 1992, p. 117). Much of Steckel and Ziebarth's paper concerns our construction and use of this instrumental variable. In the following, we discuss their criticisms and show why they are wrong.

We constructed our instrumental variable from the characteristics of manifests belonging to traders. As shown previously, traders shipped larger cargoes and relatively more prime-aged slaves (aged 10 to 30 years) than other shippers. In addition, Fogel and Engerman (1974) find that traders shipped relatively more males than females. Using a linear probability model, we predict the trading status of shippers and present the results in Table 4. Although this particular specification does not predict as well as our earlier model, we avoid the so-called "forbidden regression" problem (Bodenhorn, Guinnane, and Mroz 2013, p. 35). For regressions (1) and (2), the dependent variable equals 1 if the shipper is classified as a trader using our method of classification and 0 otherwise. As shown in regression (1), the model works quite well, correctly identifying 78 percent of the manifests as belonging either to traders or non-traders. In addition, the percentage prime-aged slaves, the percentage male, and the logarithm of the number of slaves are positively correlated with the shipper's trading status. All regression coefficients are statistically significant.

Steckel and Ziebarth (p. 15) worry about the possibility of weak instruments and suggest that spatial variation accounts for "much of the relationship between the instruments and our trader variable." We explore this possibility in regression (2) where we include indicator variables for the state of origin for the shipments. The regression coefficients for individual states are negative indicating that relative to Maryland, shipments from these states were less likely to be owned by traders. The 
coefficients for the percentage prime-aged slaves and the logarithm of the number of slaves are statistically significant and the F-statistic for joint significance is more than 52 (which is consistent with a highly reliable estimator). The apparent strength of our instruments is a direct consequence of our classification scheme. When we predict the trading status of the shipper using Steckel and Ziebarth's classification scheme, our instruments are much weaker. Perhaps this is not surprising because of measurement error. Consider regression (3) in Table 4, where the dependent variable equals Steckel and Ziebarth's measure of trading status. This regression does not predict as well as regression (1) and correctly identifies ownership for only 65 percent of the manifests. Following Steckel and Ziebarth, we include spatial variables indicating the state of origin in regression (4). For the percentage prime-aged slaves, the percentage male, and the logarithm of the number of slaves, the F-statistic for the test of joint significance is less than 10 , which suggests weak instruments. In other words, the instruments do a poor job predicting the trading status of shippers when we use Steckel and Ziebarth's method of classification. The instruments are (very) effective when we use our method of classification. Steckel and Ziebarth worry about weak instruments because they use a weak method to classify the manifests of traders.

Steckel and Ziebarth worry about situations where the instruments directly predict the heights of slaves. "For example, one could easily imagine that shipments that are predominantly male are intended for working in fields and, hence, face strong selection on heights. In this case, we would overestimate the effect of trader status on height per se though a certain type of selection would still be occurring" (p. 11). We agree that other forms of selection bias may be present in this sample and such selection may affect our empirical tests. We differ, however, as to the direction of bias. One could easily imagine situations in which migrating planters would be tempted to leave less valuable slaves behind and replace them with more valuable slaves when they got to their destination. One could also imagine that households with "better" slaves would be more likely to move, as their slaves would be 
more productive in a new environment. Consequently, planters moving with their slaves could be subject to the logic of the Alchian and Allen theorem (although we suspect that the selection would be less than for traders operating on a strictly commercial basis). Under these circumstances, the tests used in this paper would be stacked against finding evidence of sample selection bias. ${ }^{12}$

Steckel and Ziebarth (p. 11) "worry about the extent to which the 'cure' of instruments is worse tha[n] the 'disease' of bias due to classification error." To help quell their worries, we use our original indicator for trading status in the following analysis rather than our instrument. ${ }^{13}$ This specification allows us to compare the different classification methods used by Steckel and Ziebarth and ourselves and to estimate the possible effects of measurement error while controlling for temporal and spatial effects. As with our earlier specification, we find evidence of selective purchases by traders and that the measured effects are large and statistically significant.

Separate regressions are estimated for males and females and presented in Table 5 . The dependent variable is the slave's height measured in inches. The growth profile is estimated using covariates indicating the age of the slave in years. We confine our analysis to slaves aged 4 to 17 years because the effects of selection should be greatest among the youngest slaves (see discussion in Pritchett 1997). Following Steckel and Ziebarth (2015, p. 13), we group ports of departure by state of origin to control for spatial differences in the underlying slave populations. ${ }^{14} \mathrm{~A}$ fifth-order polynomial in date of birth is also included to control for temporal variation in the net nutritional status of the slave population. ${ }^{15}$ Covariates indicating shipment by a slave trader are included in the regression to measure

\footnotetext{
${ }^{12}$ Thanks to Timothy Guinnane for this comment. ${ }^{13}$ A Hausman specification test fails to reject the null of no measurement error, indicating that OLS estimation is efficient.

${ }^{13} \mathrm{~A}$ Hausman specification test fails to reject the null of no measurement error, indicating that OLS estimation is efficient.

${ }^{14}$ We caution the reader that "state of origin" refers to the location of the port of departure and not the prior residence of the slave. Consider, for example, trader James Huie who purchased slaves in the state of North Carolina and shipped them through the port of Mobile. Using Steckel and Ziebarth's terminology, the state of origin for these slaves was Alabama and not North Carolina.

${ }^{15}$ This specification is consistent with Steckel (1979, p. 375) and Pritchett and Freudenberger (1992, p. 120).
} 
the effects of selection. For comparison, we run separate regressions using different classifications of trading status. Following Steckel and Ziebarth (p. 16), we omit the covariate measuring the interaction of the slave's age and the trading status of the shipper. As we will show, the suggested modifications to our regression specification have little effect on our qualitative results. What does matter is the method for classifying the manifests. Using our method, we find strong evidence of selective purchases by traders. Using Steckel and Ziebarth's method, evidence of selection is much weaker because the regression coefficients are attenuated towards zero.

The coefficient for the variable Trader_PF indicates that the slaves shipped by traders were significantly taller than the slaves shipped by others. Males were on average 1.5 inches taller and females were 1.7 inches taller if shipped by a slave trader. For regressions (2) and (4), the variable Trader_PF is replaced with Trader_SZ (Steckel and Ziebarth's indicator for trading status). For both regressions, the estimated coefficient for Trader_SZ is relatively small. Males were 0.8 inches taller and females were 0.2 inches taller if shipped by a trader. The results using Pritchett and Freudenberger's classification are consistent with traders selecting taller slaves for shipment. It also appears that the regression results using Steckel and Ziebarth's classification are attenuated towards zero.

For their regressions, Steckel and Ziebarth include both state of origin and destination fixed effects. They argue that there are "strong reasons" to prefer their specification to ours. "The inclusions of both sets seem essential to us" (p. 13). The origin fixed effects controls for possible differences in the local slave populations whereas the destination fixed effects controls for possible differences in the uses of these slaves. Because our sample is restricted to shipments destined for New Orleans, we cannot include destination fixed effects in our regressions. (Presumably, all slaves in our sample are influenced by the same destination fixed effect.) We can include origin fixed effects and we do so with caution because of possible measurement error. Specifically, these spatial variables may be correlated with the measurement error of trading status and their inclusions may bias the regression coefficient for the 
trader variable. In Table 6, we cross tabulate the sample by the slave's state of origin to illustrate this possibility. Using the different classification schemes, we find considerable disagreement regarding the ownership of these slaves. For slaves departing from Maryland, we are in near universal agreement and agree on the ownership of 93.5 percent of these slaves. In contrast, for slaves departing from the states of Texas or Virginia, we agree on the ownership of less than half of the slaves. The difference in classification schemes is especially evident for those slaves shipped from Texas ports. Because the prevailing direction of the interregional slave trade was westward, the eastward shipment of slaves by traders (from Texas to New Orleans) is unusual and a possible indication of measurement error. Using our classification, we find that only 3.4 percent of the Texas slaves are attributed to traders whereas using Steckel and Ziebarth's classification, 48.1 percent are attributed to traders (an implausibly large percentage). This lack of consensus regarding ownership is evidence of systematic variation in measurement error by port of origin. Consequently, including spatial fixed effects may bias estimates of the trader variable, especially when using Steckel and Ziebarth's classification scheme.

Measurement error may also bias the regression coefficients for the state of origin variables. Consider the covariate indicating a shipment from a Texas port. We believe that Steckel and Ziebarth overestimated the relative number of Texas slaves shipped by traders and as a consequence, the measurement error for Trader_SZ is positively correlated with the Texas indicator variable. Because the coefficient for Trader_SZ is positive, the estimated regression coefficient for the Texas indicator variable will be reduced. Indeed, these predicts are confirmed by the regression results presented in Table 5 . For regressions (1) and (3) that include Trader_PF, the coefficient for Texas is small and not statistically significant. For regressions (2) and (4) that include Trader_SZ, the coefficients for Texas are large, negative, and statistically significant indicating that the slaves departing from this state were unusually short. If Trader_SZ is measure with error and those errors are correlated with the state of origin, then the coefficients for these spatial variables will be biased. 
The Alchian and Allen theorem predicts that the effect of selective purchases by traders should be greatest among the youngest slaves. For slaves of comparable age, only the tallest children would cover the cost of shipment. ${ }^{16}$ The results of separate regressions for boys and girls, aged 4 to 10 years, and for adolescents and teenagers, aged 11 to 17 years, are presented in Table 7. Similar to Table 5, the regression coefficient for Trader_PF is positive and statistically significant. Of particular interest, the effect of selective purchases by traders was greatest for children, aged 4 to 10 years. The regression coefficient for Trader_PF indicates that boys and girls were over two inches taller if shipped by a trader than by a non-trader. Adolescents and teenagers selected by traders were also taller than comparable slaves although the difference in stature is less evident. Overall, these regression results provide evidence of systematic selection of taller slaves by traders.

\section{Discussion}

During the antebellum period, the westward migration of slaves took two basic forms: coastwise shipments from eastern ports to the Gulf coast and inland transportation (including coffles, shipments on inland waterways and, for the latter antebellum period, railroads). Because it was largely unrecorded, quantitative estimates of this gross migration have been approximated using net migration statistics derived from decennial census data. In a recent paper, Steckel and Ziebarth $(2013$, p. 797) provide an exact headcount of 135,312 slaves shipped coastwise between 1810 and 1860 using the extant collection of coastwise manifests. The authors acknowledge that some manifests may be missing and as a consequence, they provide a lower bound estimate of the westward migration of slaves via coastal shipping. Despite this limitation, the authors make an important contribution by providing a quantitative estimate for these shipments.

\footnotetext{
${ }^{16}$ Interestingly, children shipped with their mothers were shorter, on average, than those sold singly. The shorter stature of these children suggests they were less rigorously selected when sold with their mothers (Calomiris and Pritchett 2009).
} 
Using the records of extant manifests, Steckel and Ziebarth (2013, p. 804) estimate the share of coastwise shipments made by slave traders. They estimate that traders accounted for 47.7 percent of all shipments and 53.1 percent of the westward shipments. These estimates, however, are measured with error. Steckel and Ziebarth (2013) identify the manifests of slave traders by comparing the surnames of shippers with those of identified traders. Shippers who made frequent voyages from the same port are also classified as traders. As we discussed previously, this method of classification is subject to measurement error. For the sample of New Orleans manifests analyzed in this paper, we find that Steckel and Ziebarth attribute 59 percent of the slaves to the shipments of traders. Using our classification, we find that 72 percent of the slaves were shipped by traders (see Table 1). By our calculation, they undercount the shipments of traders by approximately 13 percentage points. ${ }^{17}$

Steckel and Ziebarth did not estimate the slave trade's share of interregional migration. After all, traders transported slaves by both land and sea and estimates of interstate sales require information about both forms of transportation. Planters, for example, may have preferred overland migration whereas traders may have preferred coastwise shipping. Most planters owned draught animals that could pull wagons carrying household belongings, farm implements, and possibly enslaved children and older adults. In contrast, traders may have preferred the convenience and speed of sailing ships for their valuable cargo. Consequently, the trade may have accounted for a large share of the slaves shipped coastwise and a small share of the slaves shipped overland.

\footnotetext{
${ }^{17}$ Tadman (1989, p. 231) matched the names of "important slave traders" to those of owners listed on coastwise manifests. He finds that traders account for at least 73 percent of the slaves who arrived in New Orleans during the 1840 s.
} 


\section{Conclusions}

Pritchett and Freudenberger (1992) show that interregional traders selected taller slaves for shipment to New Orleans. In their article, they compared the heights of slaves shipped by traders with those of slaves shipped by others. Although this empirical test is relatively simple, a complicating factor is potential error in classifying manifests belonging to slave traders. Because the manifests do not list the occupations of shippers, Pritchett and Freudenberger infer this information from New Orleans sales records. A comparison of the slaves shipped by traders with those shipped by others indicates that traders shipped taller slaves. In their paper, Steckel and Ziebarth (2015) classify manifests by matching the surnames of shippers with those of slave traders located in secondary sources and newspaper advertisements. They also identify traders as frequent shippers from specific ports. Using their methodology, they find no evidence that the slaves shipped by traders were taller than those shipped by others. As we show in this paper, they misclassified the manifests of traders and this accounts for their empirical results.

In our 1992 paper, we confined our analysis to a sample of inward coastwise manifests for the port of New Orleans. Because they analyze all extant manifests and more importantly, manifests from other ports, Steckel and Ziebarth did not use our method for classifying manifests. Recall that we matched the names of shippers with those of slave sellers in New Orleans. To the best of our knowledge, comprehensive lists of slave sellers do not exist for the other ports of debarkation. Consequently, Steckel and Ziebarth use an inferior method for identifying the manifests of traders, one that is prone to error. It is because of these errors that their empirical results are attenuated towards zero. 
Table 1

Cross tabulation of shipments and slaves using different classification schemes

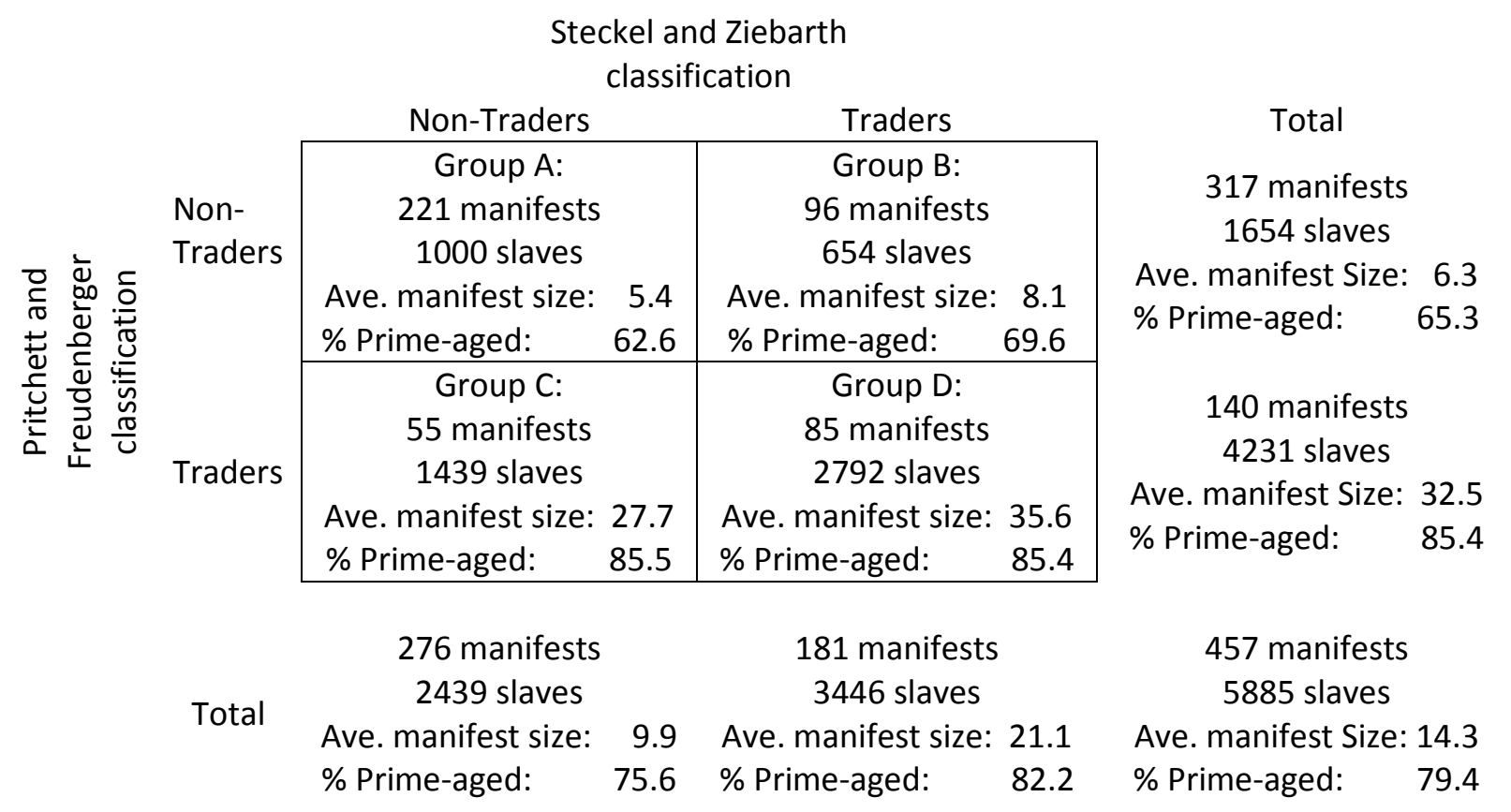

Note: Prime-aged slaves are aged 10 to 30 years.

Source: Inward Coastwise Manifests, New Orleans. 
Table 2

Height by Age for Male Slaves

Evidence From Coastwise Manifests

\begin{tabular}{lccccccc}
\hline \hline & \multicolumn{3}{c}{ Traders' Manifests } & & \multicolumn{2}{c}{ Non-Traders' Manifests } & \\
Age & Mean & $\begin{array}{c}\text { Standard } \\
\text { Deviation }\end{array}$ & $\mathrm{N}$ & Mean & $\begin{array}{c}\text { Standard } \\
\text { Deviation }\end{array}$ & $\mathrm{N}$ & $\begin{array}{c}\text { Difference } \\
\text { in Means }\end{array}$ \\
\hline 4 & 35.83 & 3.08 & 12 & 33.63 & 7.21 & 8 & 2.21 \\
5 & 42.56 & 4.19 & 9 & 39.08 & 3.29 & 8 & $3.48^{\mathrm{b}}$ \\
6 & 41.68 & 3.70 & 11 & 40.17 & 3.33 & 12 & 1.52 \\
7 & 46.04 & 2.87 & 12 & 42.64 & 5.27 & 7 & 3.40 \\
8 & 48.00 & 2.55 & 13 & 43.12 & 4.30 & 13 & $4.88^{\mathrm{a}, \mathrm{b}}$ \\
9 & 48.97 & 2.44 & 17 & 46.80 & 5.88 & 15 & $2.17^{\mathrm{a}, \mathrm{b}}$ \\
10 & 52.35 & 3.23 & 25 & 49.64 & 5.38 & 21 & $2.71^{\mathrm{a}, \mathrm{b}}$ \\
11 & 54.38 & 2.53 & 25 & 49.25 & 4.17 & 8 & $5.13^{\mathrm{a}, \mathrm{b}}$ \\
12 & 54.89 & 2.50 & 22 & 54.17 & 5.24 & 18 & 0.72 \\
13 & 56.34 & 3.02 & 25 & 54.82 & 4.08 & 11 & 1.52 \\
14 & 57.91 & 2.10 & 44 & 55.44 & 5.13 & 25 & $2.47^{\mathrm{a}, \mathrm{b}}$ \\
15 & 60.56 & 2.46 & 43 & 60.04 & 2.81 & 14 & 0.52 \\
16 & 62.92 & 1.76 & 49 & 60.50 & 5.84 & 10 & $2.42^{\mathrm{a}, \mathrm{b}}$ \\
17 & 64.27 & 2.57 & 62 & 64.37 & 3.87 & 17 & -0.10 \\
18 & 65.25 & 2.08 & 98 & 64.55 & 3.53 & 28 & 0.70 \\
19 & 66.51 & 2.00 & 106 & 66.73 & 3.20 & 23 & -0.22 \\
20 & 66.67 & 2.18 & 185 & 65.83 & 2.85 & 29 & 0.84 \\
21 & 67.54 & 2.11 & 131 & 65.77 & 2.94 & 20 & $1.77^{\mathrm{a}, \mathrm{b}}$ \\
22 & 67.23 & 2.88 & 151 & 67.00 & 3.05 & 34 & 0.23 \\
23 & 67.47 & 2.39 & 87 & 68.56 & 3.82 & 16 & -1.09 \\
24 & 67.56 & 2.24 & 108 & 66.53 & 2.59 & 24 & $1.03^{\mathrm{a}, \mathrm{b}}$ \\
ages 25-49 & 67.18 & 2.62 & 384 & 67.12 & 3.12 & 189 & 0.06 \\
\hline
\end{tabular}

${ }^{\mathrm{a}}$ The mean height in inches of the traded slaves is significantly greater than the mean height of the nontraded slaves at the five percent level (one-sided t-test).

${ }^{b}$ The mean height in inches of the traded slaves is significantly greater than the mean height of the nontraded slaves at the five percent level (one-sided Wilcoxon test).

Note: Sample includes the subset of manifests where both Steckel and Ziebarth (2015) and Pritchett and Freudenberger (1992) agree to their ownership (Groups A and D from Table 1).

Source: Inward Coastwise Manifests, New Orleans. 
Table 3

Height by Age for Female Slaves

Evidence From Coastwise Manifests

\begin{tabular}{lccccccc}
\hline \hline & \multicolumn{3}{c}{ Traders' Manifest } & & \multicolumn{2}{c}{ Non-Traders' Manifests } & \\
Age & Mean & $\begin{array}{c}\text { Standard } \\
\text { Deviation }\end{array}$ & $\mathrm{N}$ & Mean & $\begin{array}{c}\text { Standard } \\
\text { Deviation }\end{array}$ & $\mathrm{N}$ & $\begin{array}{c}\text { Difference } \\
\text { in Means }\end{array}$ \\
\hline 4 & 35.27 & 4.61 & 17 & 34.83 & 5.73 & 9 & 0.44 \\
5 & 40.30 & 4.11 & 23 & 35.10 & 5.70 & 3 & 5.20 \\
6 & 42.64 & 1.49 & 7 & 38.00 & 4.33 & 15 & $4.64^{\mathrm{a}, \mathrm{b}}$ \\
7 & 43.95 & 3.65 & 10 & 43.12 & 2.58 & 13 & 0.83 \\
8 & 47.02 & 3.93 & 21 & 46.42 & 5.99 & 13 & 0.60 \\
9 & 48.65 & 3.82 & 20 & 48.45 & 2.95 & 13 & 0.20 \\
10 & 52.71 & 3.34 & 21 & 49.05 & 5.36 & 16 & $3.66^{\mathrm{a}, \mathrm{b}}$ \\
11 & 54.12 & 2.34 & 15 & 52.00 & 2.07 & 8 & $2.12^{\mathrm{a}, \mathrm{b}}$ \\
12 & 54.58 & 2.78 & 37 & 51.19 & 4.20 & 16 & $3.39^{\mathrm{a}, \mathrm{b}}$ \\
13 & 56.89 & 3.90 & 31 & 54.27 & 5.27 & 15 & $2.63^{\mathrm{a}, \mathrm{b}}$ \\
14 & 59.03 & 2.43 & 40 & 58.16 & 3.49 & 27 & 0.87 \\
15 & 60.72 & 1.99 & 71 & 57.97 & 5.34 & 14 & $2.74^{\mathrm{a}, \mathrm{b}}$ \\
16 & 61.73 & 2.39 & 124 & 59.89 & 4.46 & 20 & $1.84^{\mathrm{a}}$ \\
17 & 62.35 & 2.14 & 111 & 61.95 & 3.93 & 10 & 0.40 \\
18 & 62.60 & 2.57 & 159 & 63.10 & 4.06 & 24 & -0.50 \\
19 & 63.02 & 2.17 & 51 & 62.25 & 2.24 & 14 & 0.77 \\
20 & 62.77 & 2.22 & 109 & 62.71 & 2.52 & 21 & 0.06 \\
21 & 63.06 & 3.10 & 25 & 63.19 & 3.32 & 8 & -0.13 \\
22 & 63.42 & 2.27 & 45 & 62.44 & 2.59 & 25 & $0.99^{\mathrm{a}, \mathrm{b}}$ \\
23 & 62.54 & 4.63 & 27 & 63.88 & 1.56 & 9 & -1.34 \\
24 & 63.53 & 2.81 & 34 & 61.04 & 4.71 & 17 & $2.49^{\mathrm{a}, \mathrm{b}}$ \\
ages $25-49$ & 62.89 & 2.26 & 173 & 62.46 & 3.67 & 139 & 0.43 \\
\hline
\end{tabular}

${ }^{a}$ The mean height in inches of the traded slaves is significantly greater than the mean height of the nontraded slaves at the five percent level (one-sided t-test).

${ }^{b}$ The mean height in inches of the traded slaves is significantly greater than the mean height of the nontraded slaves at the five percent level (one-sided Wilcoxon test).

Note: Sample includes the subset of manifests where both Steckel and Ziebarth (2015) and Pritchett and Freudenberger (1992) agree to their ownership (Groups A and D from Table 1).

Source: Inward Coastwise Manifests, New Orleans. 


\begin{tabular}{|c|c|c|c|c|}
\hline \multicolumn{5}{|c|}{$\begin{array}{c}\text { Table } 4 \\
\text { OLS Regression of Trading Status } \\
\text { Linear Probability Model }\end{array}$} \\
\hline \multirow[b]{2}{*}{ Variable } & \multicolumn{2}{|c|}{$\begin{array}{l}\text { Pritchett and } \\
\text { Freudenberger } \\
\text { Classification }\end{array}$} & \multicolumn{2}{|c|}{$\begin{array}{l}\text { Steckel and } \\
\text { Ziebarth } \\
\text { Classification }\end{array}$} \\
\hline & $(1)$ & $(2)$ & $(3)$ & $(4)$ \\
\hline Intercept $^{\mathrm{a}}$ & $\begin{array}{l}-0.251^{b} \\
(0.036)\end{array}$ & $\begin{array}{l}0.200^{b} \\
(0.066)\end{array}$ & $\begin{array}{l}0.075 \\
(0.058)\end{array}$ & $\begin{array}{l}0.376^{b} \\
(0.094)\end{array}$ \\
\hline Percent Prime Aged & $\begin{array}{l}0.259^{b} \\
(0.041)\end{array}$ & $\begin{array}{l}0.200^{b} \\
(0.040)\end{array}$ & $\begin{array}{l}0.151^{b} \\
(0.064)\end{array}$ & $\begin{array}{l}0.131^{b} \\
(0.066)\end{array}$ \\
\hline Percent Male & $\begin{array}{l}0.105^{b} \\
(0.040)\end{array}$ & $\begin{array}{c}0.053 \\
(0.041)\end{array}$ & $\begin{array}{c}0.108 \\
(0.064)\end{array}$ & $\begin{array}{c}0.102 \\
(0.069)\end{array}$ \\
\hline Slaves & $\begin{array}{c}0.192^{b} \\
(0.011)\end{array}$ & $\begin{array}{c}0.146^{b} \\
(0.013)\end{array}$ & $\begin{array}{l}0.095^{b} \\
(0.016)\end{array}$ & $\begin{array}{c}0.084^{b} \\
(0.019)\end{array}$ \\
\hline \multicolumn{5}{|c|}{ State of Origin ( $1=y e s, 0=n o)$} \\
\hline Alabama & & $\begin{array}{l}-0.406^{b} \\
(0.060)\end{array}$ & & $\begin{array}{l}-0.383^{b} \\
(0.075)\end{array}$ \\
\hline Florida & & $\begin{array}{l}-0.481^{b} \\
(0.053)\end{array}$ & & $\begin{array}{l}-0.345^{b} \\
(0.078)\end{array}$ \\
\hline Georgia & & $\begin{array}{l}-0.434^{b} \\
(0.067)\end{array}$ & & $\begin{array}{l}-0.176 \\
(0.110)\end{array}$ \\
\hline Louisiana & & $\begin{array}{l}-0.507^{b} \\
(0.058)\end{array}$ & & $\begin{array}{l}-0.249 \\
(0.269)\end{array}$ \\
\hline Mississippi & & $\begin{array}{l}-0.436^{b} \\
(0.050)\end{array}$ & & $\begin{array}{l}-0.557^{b} \\
(0.067)\end{array}$ \\
\hline North Carolina & & $\begin{array}{l}-0.410^{b} \\
(0.121)\end{array}$ & & $\begin{array}{l}-0.547^{b} \\
(0.082)\end{array}$ \\
\hline South Carolina & & $\begin{array}{l}-0.267^{b} \\
(0.064)\end{array}$ & & $\begin{array}{l}-0.267^{b} \\
(0.077)\end{array}$ \\
\hline Texas & & $\begin{array}{l}-0.459^{b} \\
(0.053)\end{array}$ & & $\begin{array}{l}-0.313^{b} \\
(0.079)\end{array}$ \\
\hline Virginia & & $\begin{array}{l}-0.141^{b} \\
(0.060)\end{array}$ & & $\begin{array}{l}-0.311^{b} \\
(0.075)\end{array}$ \\
\hline $\begin{array}{l}\text { Percent predicted } \\
\text { correctly }{ }^{c}\end{array}$ & 77.9 & 82.2 & 65.1 & 68.6 \\
\hline F-value & 110.25 & 42.32 & 16.68 & 7.16 \\
\hline Sample size & 455 & 455 & 455 & 455 \\
\hline
\end{tabular}

${ }^{\mathrm{a}}$ For regressions (2) and (4), the intercept refers to shipments originating from Baltimore Maryland.

${ }^{\mathrm{b}}$ The coefficient is statistically significant at the five percent level.

'Predicted probabilities compared to the mean of the dependent variable, converted to a binary variable, and then assessed as correct or incorrect.

Note: Heteroscedasticity consistent standard errors in parentheses. For regressions (1) and (2), the dependent variable equals 1 if shipper is classified as a trader by Pritchett and Freudenberger, 0 otherwise. For regressions (3) and (4), the dependent variable equals 1 if shipper is classified as a trader by Steckel and Ziebarth, 0 otherwise.

Independent variables are defined as follows: 
Percent Prime aged $=$ Number of slaves aged 11 to 30 years divided by number of slaves listed on manifest.

Percent Male $=$ Number of male slaves divided by number of slaves on manifest.

Slaves $=$ Natural logarithm of number of slaves listed on manifest.

State of origin is defined as follows:

Alabama $=1$ if port of embarkation was Mobile, 0 otherwise.

Florida $=1$ if port of embarkation was Apalachicola, Key West, Pensacola, St. Marks, or Tampa Bay, 0 otherwise.

Georgia $=1$ if port of embarkation was Savannah, 0 otherwise.

Louisiana $=1$ if port of embarkation was New Orleans, 0 otherwise.

Mississippi=1 if port of embarkation was Bay St. Louis, or Pearlington, 0 otherwise.

North Carolina=1 if port of embarkation was Wilmington, 0 otherwise.

South Carolina $=1$ if port of embarkation was Charleston, 0 otherwise.

Texas $=1$ if port of embarkation was Galveston, Port Lavaca, Matagorda, Port Isabel, or Sabine, 0 otherwise.

Virginia=1 if port of embarkation was Alexandria, Norfolk, Petersburg, or Richmond, 0 otherwise. Source: Inward Coastwise Manifests, New Orleans. 
Table 5

OLS Regression of slave heights

Ages 4-17 years

\begin{tabular}{|c|c|c|c|c|}
\hline \multirow{2}{*}{ Variable } & \multicolumn{2}{|c|}{ Males Slaves } & \multicolumn{2}{|c|}{ Female Slaves } \\
\hline & $(1)$ & $(2)$ & $(3)$ & $(4)$ \\
\hline Intercept $\mathrm{t}^{\mathrm{a}}$ & $\begin{array}{l}220.461^{b} \\
(101.297)\end{array}$ & $\begin{array}{c}188.666 \\
(101.759)\end{array}$ & $\begin{array}{l}16.354^{b} \\
(87.211)\end{array}$ & $\begin{array}{l}-12.461 \\
(88.021)\end{array}$ \\
\hline $\begin{array}{l}\text { Trader_PF } \\
(1=y e s, 0=\text { no) }\end{array}$ & $\begin{array}{l}1.535^{b} \\
(0.349)\end{array}$ & & $\begin{array}{l}1.687^{b} \\
(0.330)\end{array}$ & \\
\hline $\begin{array}{l}\text { Trader_SZ } \\
\text { (1=yes, } 0=\text { no })\end{array}$ & & $\begin{array}{l}0.760^{b} \\
(0.283)\end{array}$ & & $\begin{array}{c}0.221 \\
(0.244)\end{array}$ \\
\hline \multicolumn{5}{|c|}{ Age at time of shipment ( $1=y e s, 0=$ no) } \\
\hline Age 5 years & $\begin{array}{l}4.574^{b} \\
(1.023)\end{array}$ & $\begin{array}{l}4.617^{b} \\
(1.031)\end{array}$ & $\begin{array}{l}3.445^{b} \\
(0.813)\end{array}$ & $\begin{array}{l}3.557^{b} \\
(0.822)\end{array}$ \\
\hline Age 6 years & $\begin{array}{l}5.934^{b} \\
(0.932)\end{array}$ & $\begin{array}{l}6.077^{b} \\
(0.939)\end{array}$ & $\begin{array}{l}4.968^{b} \\
(0.826)\end{array}$ & $\begin{array}{l}4.770^{b} \\
(0.836)\end{array}$ \\
\hline Age 7 years & $\begin{array}{l}7.952^{\mathrm{b}} \\
(1.001)\end{array}$ & $\begin{array}{l}8.006^{b} \\
(1.008)\end{array}$ & $\begin{array}{l}8.974^{b} \\
(0.787)\end{array}$ & $\begin{array}{l}8.878^{b} \\
(0.796)\end{array}$ \\
\hline Age 8 years & $\begin{array}{l}9.937^{b} \\
(0.902)\end{array}$ & $\begin{array}{l}10.085^{b} \\
(0.907)\end{array}$ & $\begin{array}{l}10.915^{b} \\
(0.779)\end{array}$ & $\begin{array}{l}10.864^{b} \\
(0.788)\end{array}$ \\
\hline Age 9 years & $\begin{array}{l}11.905^{b} \\
(0.903)\end{array}$ & $\begin{array}{l}11.811^{b} \\
(0.910)\end{array}$ & $\begin{array}{l}12.782^{b} \\
(0.791)\end{array}$ & $\begin{array}{l}12.682^{b} \\
(0.800)\end{array}$ \\
\hline Age 10 years & $\begin{array}{l}14.650^{\mathrm{b}} \\
(0.840)\end{array}$ & $\begin{array}{l}14.652^{b} \\
(0.846)\end{array}$ & $\begin{array}{l}15.149^{b} \\
(0.754)\end{array}$ & $\begin{array}{l}14.951^{b} \\
(0.763)\end{array}$ \\
\hline Age 11 years & $\begin{array}{l}16.204^{b} \\
(0.905)\end{array}$ & $\begin{array}{l}16.467^{b} \\
(0.910)\end{array}$ & $\begin{array}{l}17.752^{b} \\
(0.827)\end{array}$ & $\begin{array}{l}17.769^{b} \\
(0.838)\end{array}$ \\
\hline Age 12 years & $\begin{array}{l}18.637^{b} \\
(0.842)\end{array}$ & $\begin{array}{l}18.718^{b} \\
(0.848)\end{array}$ & $\begin{array}{l}17.643^{b} \\
(0.732)\end{array}$ & $\begin{array}{l}17.658^{b} \\
(0.742)\end{array}$ \\
\hline Age 13 years & $\begin{array}{l}19.142^{b} \\
(0.891)\end{array}$ & $\begin{array}{l}19.411^{b} \\
(0.895)\end{array}$ & $\begin{array}{l}20.343^{b} \\
(0.757)\end{array}$ & $\begin{array}{l}20.195^{b} \\
(0.766)\end{array}$ \\
\hline Age 14 years & $\begin{array}{l}20.606^{b} \\
(0.847)\end{array}$ & $\begin{array}{l}20.614^{b} \\
(0.853)\end{array}$ & $\begin{array}{l}22.698^{b} \\
(0.716)\end{array}$ & $\begin{array}{l}22.631^{b} \\
(0.726)\end{array}$ \\
\hline Age 15 years & $\begin{array}{l}23.227^{b} \\
(0.869)\end{array}$ & $\begin{array}{l}23.330^{b} \\
(0.875)\end{array}$ & $\begin{array}{l}23.994^{b} \\
(0.710)\end{array}$ & $\begin{array}{l}23.986^{b} \\
(0.719)\end{array}$ \\
\hline Age 16 years & $\begin{array}{l}25.325^{b} \\
(0.858)\end{array}$ & $\begin{array}{l}25.575^{b} \\
(0.861)\end{array}$ & $\begin{array}{l}25.166^{b} \\
(0.683)\end{array}$ & $\begin{array}{l}25.256^{b} \\
(0.691)\end{array}$ \\
\hline Age 17 years & $\begin{array}{l}26.834^{b} \\
(0.860)\end{array}$ & $\begin{array}{l}27.085^{b} \\
(0.863)\end{array}$ & $\begin{array}{l}25.911^{b} \\
(0.690)\end{array}$ & $\begin{array}{l}25.975^{b} \\
(0.698)\end{array}$ \\
\hline \multicolumn{5}{|c|}{ State of origin ( $1=y e s, 0=$ no $)$} \\
\hline Alabama & $\begin{array}{c}0.641 \\
(0.438)\end{array}$ & $\begin{array}{c}0.465 \\
(0.446)\end{array}$ & $\begin{array}{l}-0.026 \\
(0.369)\end{array}$ & $\begin{array}{l}-0.464 \\
(0.390)\end{array}$ \\
\hline Florida & $\begin{array}{c}0.061 \\
(0.605)\end{array}$ & $\begin{array}{l}-0.772 \\
(0.559)\end{array}$ & $\begin{array}{c}0.936 \\
(0.568)\end{array}$ & $\begin{array}{c}-0.439 \\
(0.517)\end{array}$ \\
\hline Georgia & $\begin{array}{c}0.375 \\
(1.102)\end{array}$ & $\begin{array}{c}-0.720 \\
(1.069)\end{array}$ & $\begin{array}{c}0.265 \\
(1.201)\end{array}$ & $\begin{array}{c}-1.212 \\
(1.184)\end{array}$ \\
\hline South Carolina & $\begin{array}{l}-1.033^{b} \\
(0.490)\end{array}$ & $\begin{array}{l}-1.261^{b} \\
(0.497)\end{array}$ & $\begin{array}{l}-0.818 \\
(0.482)\end{array}$ & $\begin{array}{l}-1.547^{b} \\
(0.469)\end{array}$ \\
\hline
\end{tabular}




\begin{tabular}{|c|c|c|c|c|}
\hline Texas & $\begin{array}{l}-0.815 \\
(0.731)\end{array}$ & $\begin{array}{l}-1.709^{b} \\
(0.689)\end{array}$ & $\begin{array}{l}-0.013 \\
(0.612)\end{array}$ & $\begin{array}{l}-1.296^{b} \\
(0.572)\end{array}$ \\
\hline Virginia & $\begin{array}{l}-0.101 \\
(0.352)\end{array}$ & $\begin{array}{l}-0.050 \\
(0.366)\end{array}$ & $\begin{array}{c}0.140 \\
(0.258)\end{array}$ & $\begin{array}{c}0.113 \\
(0.285)\end{array}$ \\
\hline $\begin{array}{l}\text { Light skin color } \\
\text { (1=yes, } 0=\text { no) }\end{array}$ & $\begin{array}{l}-0.009 \\
(0.341)\end{array}$ & $\begin{array}{l}-0.065 \\
(0.344)\end{array}$ & $\begin{array}{c}0.071 \\
(0.287)\end{array}$ & $\begin{array}{c}0.000 \\
(0.290)\end{array}$ \\
\hline \multicolumn{5}{|c|}{ Date $=($ birth year -1790$) / 10$} \\
\hline Date & $\begin{array}{l}-240.873 \\
(145.953)\end{array}$ & $\begin{array}{l}-201.047 \\
(146.707)\end{array}$ & $\begin{array}{c}37.600 \\
(125.638)\end{array}$ & $\begin{array}{c}79.440 \\
(126.809)\end{array}$ \\
\hline Date $^{2}$ & $\begin{array}{l}120.207 \\
(81.927)\end{array}$ & $\begin{array}{l}101.828 \\
(82.405)\end{array}$ & $\begin{array}{l}-26.516 \\
(70.437)\end{array}$ & $\begin{array}{l}-48.946 \\
(71.116)\end{array}$ \\
\hline Date $^{3}$ & $\begin{array}{l}-28.700 \\
(22.422)\end{array}$ & $\begin{array}{l}-24.731 \\
(22.564)\end{array}$ & $\begin{array}{c}8.467 \\
(19.243)\end{array}$ & $\begin{array}{c}14.307 \\
(19.434)\end{array}$ \\
\hline Date $^{4}$ & $\begin{array}{c}3.286 \\
(2.995)\end{array}$ & $\begin{array}{c}2.890 \\
(3.015)\end{array}$ & $\begin{array}{l}-1.247 \\
(2.564)\end{array}$ & $\begin{array}{l}-1.987 \\
(2.591)\end{array}$ \\
\hline Date $^{5}$ & $\begin{array}{l}-0.145 \\
(0.156)\end{array}$ & $\begin{array}{l}-0.131 \\
(0.157)\end{array}$ & $\begin{array}{c}0.068 \\
(0.134)\end{array}$ & $\begin{array}{c}0.105 \\
(0.135)\end{array}$ \\
\hline $\mathrm{R}^{2}$ & 0.817 & 0.814 & 0.843 & 0.840 \\
\hline F-value & 145.920 & 143.430 & 230.060 & 223.990 \\
\hline Sample size & 878 & 878 & 1138 & 1138 \\
\hline
\end{tabular}

${ }^{a}$ For regressions (1), (2), and (3), the intercept refers to slaves, aged 4 years, and shipped by a nontrader. For regressions (4), (5), and (6), the intercept refers to dark-skinned males, aged 4 years, shipped from a port in Maryland by a non-trader.

${ }^{\text {b}}$ The coefficient is statistically significant at the five percent level.

Note: The dependent variable is the slave's height measured in inches. Trading status of shipper is defined as follows:

Trader_PF $=1$ if shipper is classified as a trader by Pritchett and Freudenberger, 0 otherwise.

Trader_SZ=1 if shipper is classified as a trader by Steckel and Ziebarth, 0 otherwise.

State of origin is defined as follows:

Virginia=1 if port of embarkation was Alexandria, Norfolk, Petersburg, or Richmond, 0 otherwise.

Florida $=1$ if port of embarkation was Apalachicola, Pensacola, St. Marks, or Tampa Bay, 0 otherwise.

South Carolina $=1$ if port of embarkation was Charleston, 0 otherwise.

Texas $=1$ if port of embarkation was Galveston, Lavaca, Matagorda, or Port Isabel, 0 otherwise.

Alabama $=1$ if port of embarkation was Mobile, 0 otherwise.

Georgia $=1$ if port of embarkation was Savannah, 0 otherwise.

Source: Inward Coastwise Manifests, New Orleans. 
Table 6

Relative number of slaves shipped by traders

By classification scheme and port of origin

\begin{tabular}{|c|c|c|c|c|}
\hline \multirow[b]{2}{*}{ State of origin } & \multirow[b]{2}{*}{$\begin{array}{l}\text { Number } \\
\text { of slaves }\end{array}$} & \multicolumn{2}{|c|}{$\begin{array}{l}\text { Percent of slaves } \\
\text { shipped by traders }\end{array}$} & \multirow{2}{*}{$\begin{array}{c}\text { Percent } \\
\text { agreement } \\
\text { on } \\
\text { ownership }\end{array}$} \\
\hline & & $\begin{array}{c}\text { Pritchett \& } \\
\text { Freudenberger's } \\
\text { classification }\end{array}$ & $\begin{array}{l}\text { Steckel \& Ziebarth's } \\
\text { classification }\end{array}$ & \\
\hline Alabama & 1057 & $57.6 \%$ & $38.1 \%$ & $55.7 \%$ \\
\hline Florida & 301 & $3.0 \%$ & $27.6 \%$ & $69.4 \%$ \\
\hline Georgia & 113 & $1.8 \%$ & $24.8 \%$ & $73.5 \%$ \\
\hline Maryland & 1605 & $97.5 \%$ & $92.8 \%$ & $93.5 \%$ \\
\hline South Carolina & 479 & $50.5 \%$ & $42.0 \%$ & $55.1 \%$ \\
\hline Texas & 235 & $3.4 \%$ & $48.1 \%$ & $48.5 \%$ \\
\hline Virginia & 2077 & $86.4 \%$ & $54.1 \%$ & $49.0 \%$ \\
\hline
\end{tabular}


Table 7

OLS Regression of slave heights

Ages 4-10 years and 11-17 years

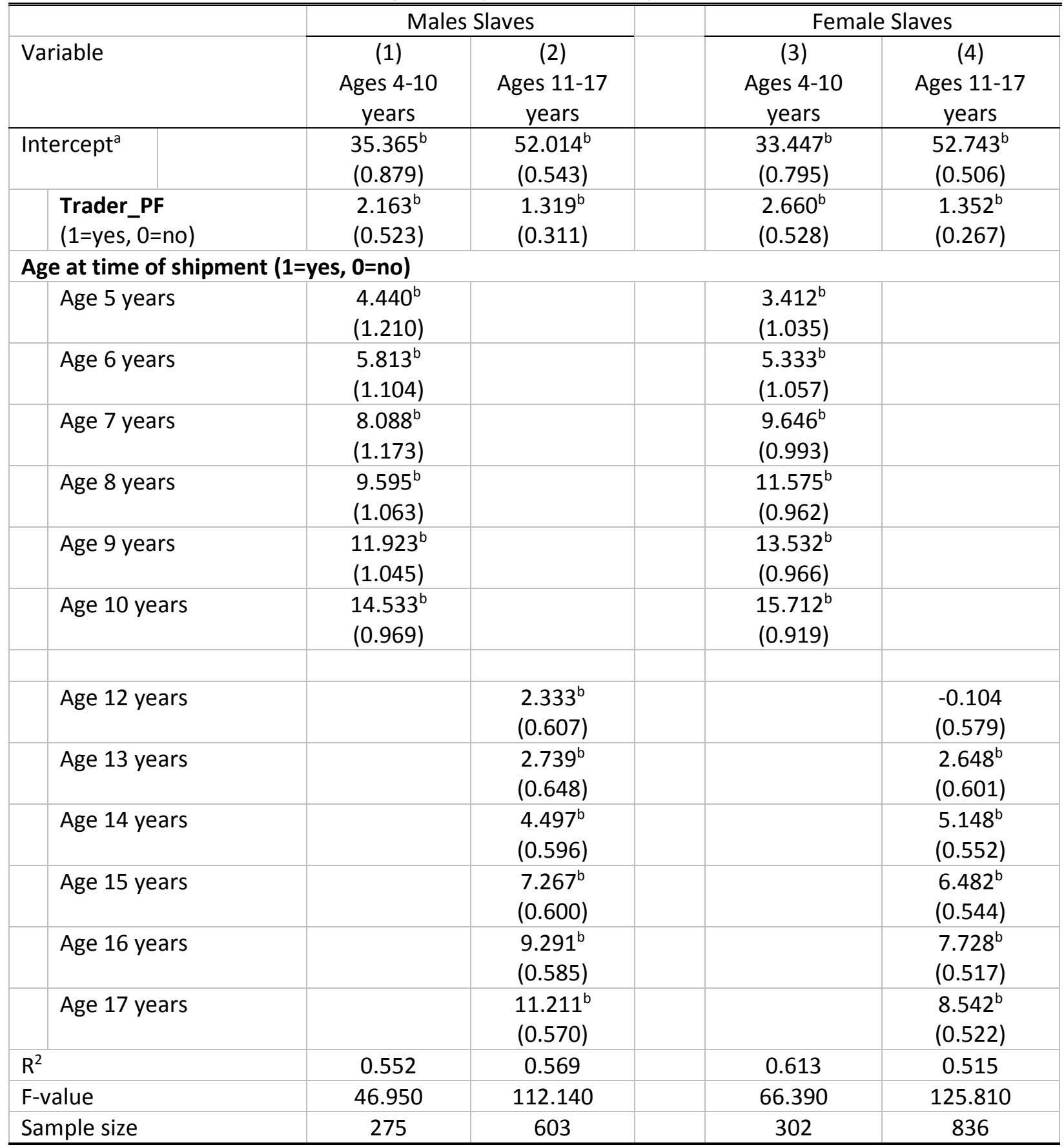

${ }^{\mathrm{a}}$ For regressions (1) and (3), the intercept refers to slaves, aged 4 years, shipped by a non-trader. For regressions (2), and (4), the intercept refers to slaves, aged 11 years, shipped by a non-trader.

${ }^{b}$ The coefficient is statistically significant at the five percent level.

Note: The dependent variable is the slave's height measured in inches. Trader_PF=1 if shipper is classified as a trader by Pritchett and Freudenberger, 0 otherwise.

Source: Inward Coastwise Manifests, New Orleans. 


\section{References}

Bancroft, Frederic, Slave Trading in the Old South, Baltimore: J. H. Furst Company, 1931.

Bodenhorn, Howard, Timothy Guinnane and Thomas Mroz "Problems of Sample-Selection Bias in the Historical Heights Literature: A Theoretical and Econometric Analysis." Yale University Economic Growth Center Discussion Paper No. 1023 (May 2013).

. "Caveat Lector: Sample Selection in Historical Heights and the Interpretation of Early

Industrializing Economies." NBER working paper 19955 (March 2014).

Calomiris, Charles and Jonathan Pritchett, "Preserving Slave Families for Profit: Traders' Incentives and Pricing in the New Orleans Slave Market," Journal of Economic History 69 (December 2009), pp. 986-1011. Also NBER working paper 14281.

Choo, Eugene and Jean Eid. "Interregional Price Difference in the New Orleans Auctions Market for Slaves." Journal of Business and Economic Statistics 26, no. 4 (October 2008), pp. 486-509.

Fogel, Robert W., and Stanley L. Engerman. Time on the Cross: The Economics of American Negro Slavery. Boston: Little Brown 1974.

Freudenberger, Herman and Jonathan B. Pritchett, "The Domestic United States Slave Trade: New Evidence," Journal of Interdisciplinary History, 21 (Winter, 1991), pp. 447-477.

Greenwald, Bruce C. and Robert R. Glasspiegel. "Adverse Selection in the Market for Slaves: New Orleans: 1830-1860." Quarterly Journal of Economics 98, no. 3 (August, 1983): 479-499.

Johnson, Walter, Soul By Soul: Life inside the Antebellum Slave Market. Cambridge: Harvard University Press 1999.

Komlos, John, and Bjorn Alecke, "The Economics of Antebellum Slave Heights Reconsidered," Journal of Interdisciplinary History, 26 (Winter, 1996), pp. 437-457.

Kotlikoff, Laurence, "The Structure of Slave Prices in New Orleans, 1804 to 1862." Economic Inquiry, 17 (October, 1979), pp. 496-517.

Kotlikoff, Laurence. “Quantitative Description of the New Orleans Slave Market, 1804 to 1862,” in Without Consent or Contract: Markets and Production, Technical Papers, 1, Robert W. Fogel and Stanley L. Engerman (eds.), New York: W. W. Norton, 1992. pp. 31-53.

Levendis, John. "Qualities and Effective-Quantities of Slaves in New Orleans." Southwestern Economic Review 34, no. 1 (Spring, 2007): 161-177. 
Margo, Robert A., and Richard H. Steckel, "The Heights of American Slaves: New Evidence on Slave Nutrition and Health," Social Science History, Vol. 6, No. 4, (Autumn, 1982), pp. 516-538.

New Orleans City Archive, "Slaves arrived in New Orleans, 1831," 1831.

Oxford American College Dictionary. New York: G.P. Putnam's Sons, c2002.

Phillips, Ulrich B. Life \& Labor in the Old South Boston: Little Brown and Company. 1929.

Pritchett, Jonathan "The Interregional Slave Trade and the Selection of Slaves for the New Orleans Market," Journal of Interdisciplinary History, 28 (Summer, 1997), pp. 57-85.

Pritchett, Jonathan and Richard M. Chamberlain, "Selection in the Market for Slaves: New Orleans, 1830-1860," Quarterly Journal of Economics, 108 (May, 1993), pp. 461-473.

Pritchett, Jonathan and Herman Freudenberger, "A Peculiar Sample: The Selection of Slaves for the New Orleans Market," Journal of Economic History, 52 (March, 1992), pp. 109-127.

Steckel, Richard, "Slave Height Profiles from Coastwise Manifests," Explorations in Economic History, 16 (October, 1979), pp. 363-380.

Steckel, Richard and Nicolas Ziebarth, "A Troublesome Statistic: Traders and Coastal Shipments in the Westward Movement of Slaves," Journal of Economic History 73 (September 2013), pp. 792-809.

Steckel, Richard and Nicolas Ziebarth, "Selectivity and Measured Catch-up Growth of American Slaves: The Hunt for Bias" working paper 2015.

Tadman, Michael, "Slave Trading in the Ante-Bellum South: An Estimate of the Extent of the Inter-Regional Slave Trade." Journal of American Studies 13 (August 1979), pp. 195-220.

Tadman, Michael, Speculators and Slaves: Masters, Traders, and Slaves in the Old South. Madison: University of Wisconsin Press, 1989.

Webster's New World Dictionary, Second College Edition. New York: Prentice Hall Press 1984. 


\section{Appendix}

A Peculiar Sample: A reply to Steckel and Ziebarth* 
As seen in figure $A 1$, most of the manifests in groups $A$ and $B$ are relatively small whereas most of the manifests in groups $C$ and $D$ are relatively large. Based on the size distributions, it appears that Steckel and Ziebarth have confused groups B and C. In particular, the manifests in group B are implausibly small for slave traders and those in group $\mathrm{C}$ are implausibly large for non-traders. The age distributions for each group provide additional evidence of misclassification by Steckel and Ziebarth. As seen in figure $A 2$, the age distribution for group $A$ (consensus non-traders) is similar to that for group $B$ and the age distribution for group $C$ is similar to that for group $D$ (consensus traders). Once again, it appears that Steckel and Ziebarth misclassify the manifests in group B as belonging to slave traders and the manifests in group $\mathrm{C}$ as belonging to non-traders. 


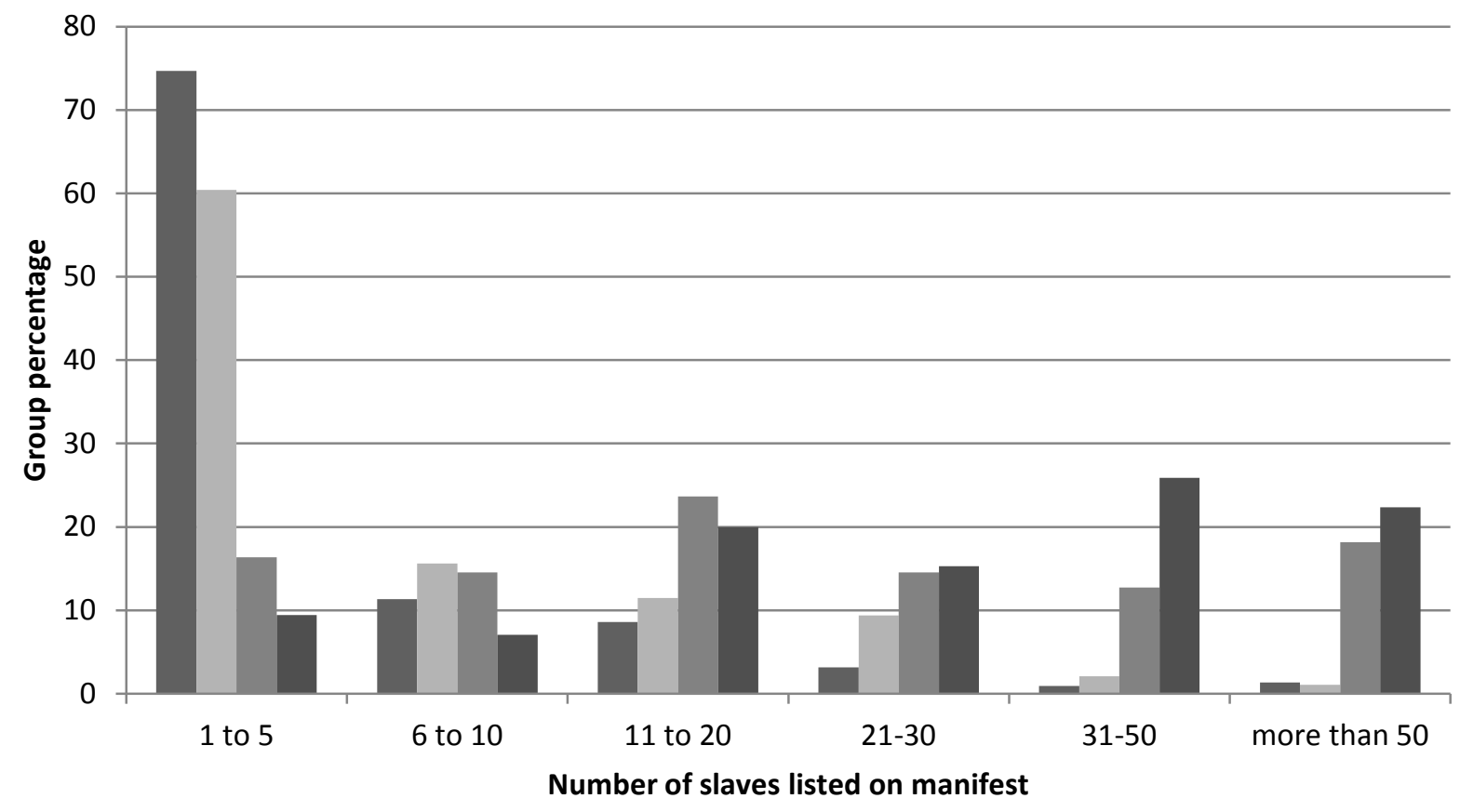

- Group A Group B - Group C $\square$ Group D

Figure A1 - Frequency distribution of manifest size by group.

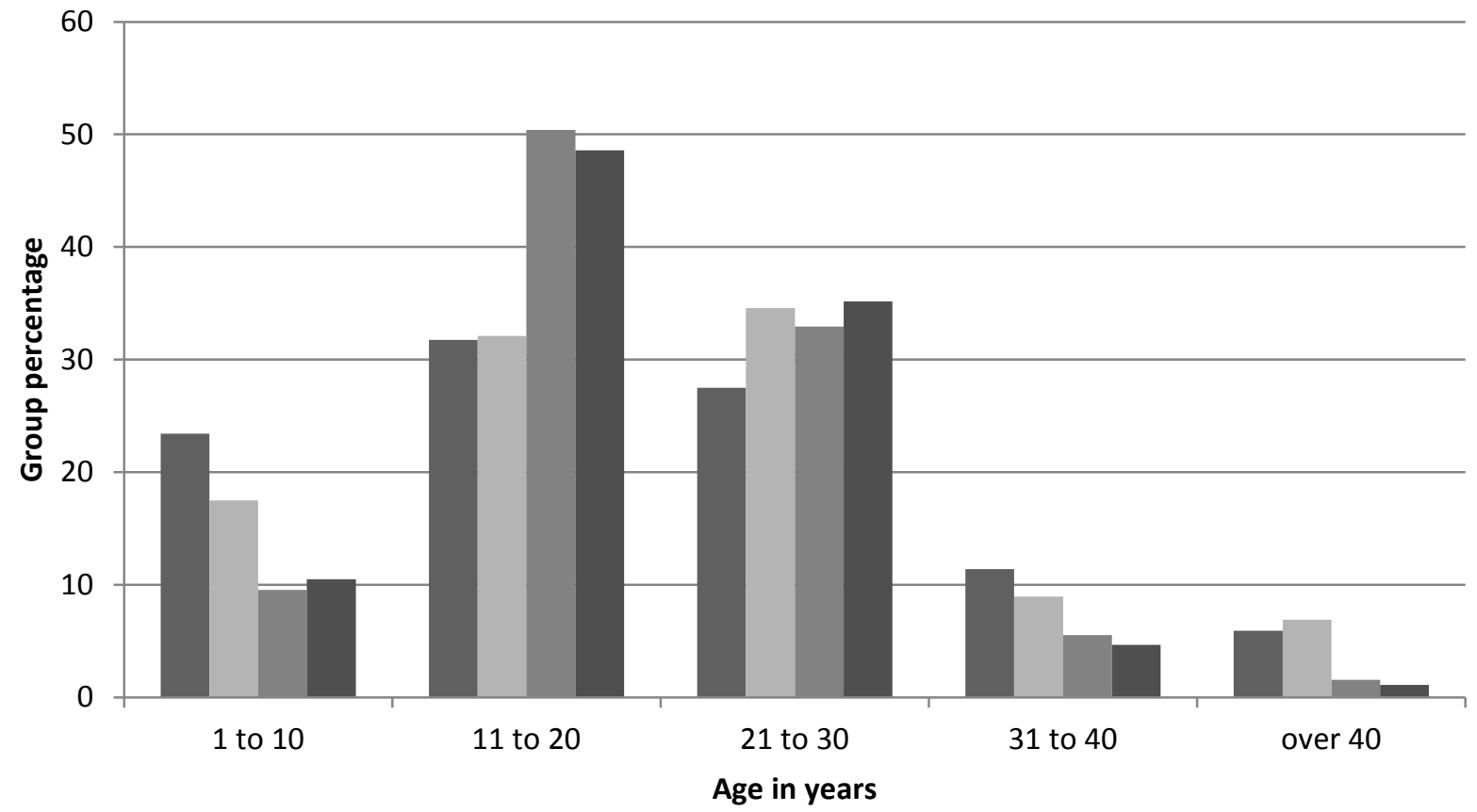

Group A $\square$ Group B $\square$ Group C $\square$ Group D

Figure A2 -- Age distribution by group. 
Table A1

Traders misclassified as non-traders by Steckel and Ziebarth Evidence from certificates of good character and New Orleans sales during 1830

\begin{tabular}{|c|c|c|c|c|c|c|}
\hline \multirow[b]{2}{*}{ Trader/shipper } & \multicolumn{2}{|c|}{ Sold in New Orleans } & \multicolumn{3}{|c|}{ Slaves purchased outside Louisiana } & \multirow{2}{*}{$\begin{array}{c}\text { Local } \\
\text { purchases } \\
\text { number of } \\
\text { local slaves }\end{array}$} \\
\hline & $\begin{array}{l}\text { Number } \\
\text { of } \\
\text { buyers }\end{array}$ & $\begin{array}{l}\text { Number of } \\
\text { slaves }\end{array}$ & $\begin{array}{l}\text { number of } \\
\text { sellers }\end{array}$ & $\begin{array}{c}\text { number of } \\
\text { slaves }\end{array}$ & $\begin{array}{l}\text { previously } \\
\text { owned by } \\
\text { trader }\end{array}$ & \\
\hline James Huie & 42 & 114 & 59 & 80 & 2 & 28 \\
\hline Robert Huie & 17 & 24 & 14 & 24 & 0 & 0 \\
\hline Robert Boyce & 11 & 13 & 11 & 12 & 0 & 1 \\
\hline Richard Brenan & 3 & 4 & 4 & 4 & 0 & 0 \\
\hline Zachariah Bugg & 4 & 12 & 11 & 11 & 0 & 0 \\
\hline Leon Chabert & 20 & 59 & 36 & 39 & 0 & 19 \\
\hline $\begin{array}{l}\text { Benjamin C. } \\
\text { Eaton }\end{array}$ & 7 & 25 & 10 & 10 & 0 & 14 \\
\hline Thomas Boudar & 53 & 91 & 74 & 85 & 0 & 2 \\
\hline $\begin{array}{l}\text { Giovanni } \\
\text { Baptiste Phillippi }\end{array}$ & 21 & 26 & 20 & 22 & 0 & 4 \\
\hline $\begin{array}{l}\text { Alexander } \\
\text { Bannister } \\
\text { Puryear }\end{array}$ & 29 & 68 & 58 & 68 & 0 & 0 \\
\hline $\begin{array}{l}\text { Thomas Boniface } \\
\text { Small }\end{array}$ & 24 & 47 & 40 & 42 & 0 & 0 \\
\hline Paul Pascal & 6 & 7 & 6 & 7 & 0 & 0 \\
\hline $\begin{array}{l}\text { James P. } \\
\text { Wilkinson }\end{array}$ & 6 & 25 & 20 & 25 & 0 & 0 \\
\hline $\begin{array}{l}\text { William } \\
\text { Williamson }\end{array}$ & 1 & 2 & 1 & 1 & 0 & 1 \\
\hline $\begin{array}{l}\text { Clement } \\
\text { Townsend }\end{array}$ & 43 & 144 & 51 & 67 & 0 & 72 \\
\hline
\end{tabular}

Source: New Orleans Notarial Archives 1830, various volumes. 
Table A2

Shippers classified as traders by Steckel and Ziebarth

Shippers matched with slave traders who were identified in secondary sources

\begin{tabular}{|c|c|c|c|c|c|c|c|}
\hline 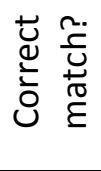 & Date & Ship & Port & slaves & $\begin{array}{c}\text { Name of } \\
\text { Shipper } \\
\text { (from Steckel) }\end{array}$ & $\begin{array}{l}\text { Name of Owner } \\
\text { (from manifest) }\end{array}$ & Name(s) of "Matched" Trader(s) \\
\hline & $11 / 8 / 51$ & $\begin{array}{l}\text { Steamship } \\
\text { Louisiana }\end{array}$ & Galveston & 1 & AUSTIN & $\begin{array}{l}\text { H. Austin } \\
\text { (Texas) }\end{array}$ & $\begin{array}{l}\text { Robert Austin (Bancroft, p. 175) } \\
\text { Nat. Austin (Bancroft, p. 37) }\end{array}$ \\
\hline & $1 / 6 / 53$ & $\begin{array}{l}\text { Schooner } \\
\text { Lincoln }\end{array}$ & St. Marks & 10 & BRYAN & $\begin{array}{l}\text { Hardy Bryan } \\
\text { (Georgia) }\end{array}$ & $\begin{array}{l}\text { Joseph Bryan (Bancroft, p. 223) } \\
\text { A. Bryan (Bancroft, p. 223) }\end{array}$ \\
\hline & $1 / 6 / 53$ & $\begin{array}{l}\text { Schooner } \\
\text { Lincoln }\end{array}$ & St. Marks & 12 & BRYAN & Hardy Bryan & $\begin{array}{l}\text { Joseph Bryan (Bancroft, p. 223) } \\
\text { A. Bryan (Bancroft, p. 223) }\end{array}$ \\
\hline & $11 / 21 / 35$ & Brig Ajax & Norfolk & 100 & FOSTER & W. Atkins & $\begin{array}{l}\text { Hugh L. Foster (Bancroft p. 128) } \\
\text { Thomas Foster (Bancroft p. 313) }\end{array}$ \\
\hline & $11 / 20 / 31$ & Brig Ajax & Norfolk & 42 & FOSTER & J. B. Purley & $\begin{array}{l}\text { Hugh L. Foster (Bancroft p. 128) } \\
\text { Thomas Foster (Bancroft p. 313) }\end{array}$ \\
\hline & $12 / 16 / 40$ & $\begin{array}{l}\text { Ship } \\
\text { Tippecanoe }\end{array}$ & Baltimore & 9 & HARKER & Thomas Ruder & William Harker (Bancroft, p. 35) \\
\hline & $2 / 18 / 28$ & $\begin{array}{l}\text { Schooner } \\
\text { Orleans }\end{array}$ & Mobile & 22 & HARRIS & $\begin{array}{l}\text { Benj. D. Harris } \\
\text { (Virginia) }\end{array}$ & J. Y. Harris (Tadman, p. 267) \\
\hline & $2 / 23 / 46$ & $\begin{array}{l}\text { Steamship } \\
\text { New York }\end{array}$ & Galveston & 5 & HARRIS & $\begin{array}{l}\text { J. T. Harris } \\
\text { (Texas) }\end{array}$ & J. Y. Harris (Tadman, p. 267 - S. Car.) \\
\hline & $1 / 20 / 43$ & $\begin{array}{l}\text { Steamship } \\
\text { Cincinnati }\end{array}$ & Mobile & 28 & LEE & $\begin{array}{l}\text { J. B. Lee } \\
\text { (Alabama) }\end{array}$ & $\begin{array}{l}\text { N. M. Lee (Bancroft, p. 97) } \\
\text { Joshua Lee (Bancroft, p. 126-7) } \\
\text { Hutson Lee (Bancroft, p. 176) }\end{array}$ \\
\hline & $11 / 11 / 51$ & Bark Acadia & Charleston & 38 & LOGAN & $\begin{array}{l}\text { G(eorge) } \\
\text { W(illiam) Logan }\end{array}$ & $\begin{array}{l}\text { C. M. Logan (Charleston City Gazette Date: } 10-18-1825) \\
\text { Richard Logan (Richmond Enquirer; Date: } 12-10-1836 \text { ) }\end{array}$ \\
\hline & $4 / 19 / 43$ & $\begin{array}{l}\text { Schooner } \\
\text { Badger }\end{array}$ & Charleston & 4 & LOGAN & $\begin{array}{l}\text { Thomas M. } \\
\text { Logan (New } \\
\text { Orleans) }\end{array}$ & $\begin{array}{l}\text { C. M. Logan (Charleston City Gazette Date: 10-18-1825) } \\
\text { Richard Logan (Richmond Enquirer; Date: 12-10-1836) }\end{array}$ \\
\hline
\end{tabular}


Table A2

Shippers classified as traders by Steckel and Ziebarth

Shippers matched with slave traders who were identified in secondary sources

\begin{tabular}{|c|c|c|c|c|c|c|c|}
\hline 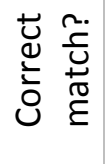 & Date & Ship & Port & slaves & $\begin{array}{c}\text { Name of } \\
\text { Shipper } \\
\text { (from Steckel) }\end{array}$ & $\begin{array}{l}\text { Name of Owner } \\
\text { (from manifest) }\end{array}$ & Name(s) of "Matched" Trader(s) \\
\hline & $2 / 12 / 41$ & Brig Michigan & Charleston & 13 & MCDONALD & G. A. McDowell & $\begin{array}{l}\text { John M. McDonald (Bancroft, p. 142) } \\
\text { Hugh McDonald (Bancroft, 276) }\end{array}$ \\
\hline & $6 / 8 / 42$ & $\begin{array}{l}\text { Schooner } \\
\text { Savannah }\end{array}$ & Savannah & 9 & MILLS & $\begin{array}{l}\text { Chas. F. Mills } \\
\text { (Savannah) }\end{array}$ & Chas. Mills (Richmond Enquirer; Date: 12-24-1833) \\
\hline & $6 / 14 / 51$ & $\begin{array}{l}\text { Steamer } \\
\text { Mexico }\end{array}$ & Galveston & 3 & MILLS & S. Mills (Texas) & Chas. Mills (Richmond Enquirer; Date: 12-24-1833) \\
\hline & $5 / 22 / 45$ & $\begin{array}{l}\text { Schooner } \\
\text { Monmouth }\end{array}$ & Mobile & 24 & MYERS & $\begin{array}{l}\text { Ezekiel Myers } \\
\text { (Richmond) }\end{array}$ & E. Myers (Bancroft, p. 92) \\
\hline & $11 / 5 / 31$ & Brig Mary & Charleston & 5 & OHARA & $\begin{array}{l}\text { Henry O’Hara } \\
\text { (Charleston) }\end{array}$ & Henry O'Hara (Charleston City Gazette; Date: 05-15-1823) \\
\hline & $12 / 15 / 41$ & $\begin{array}{l}\text { Schooner } \\
\text { Exchange }\end{array}$ & Savannah & 7 & PICKARD & $\begin{array}{l}\text { Y. S. Pickard } \\
\text { (Savannah) }\end{array}$ & Pickard \& Cox, (Tadman p. 258) \\
\hline & $4 / 14 / 27$ & $\begin{array}{l}\text { Schooner } \\
\text { James } \\
\text { Monroe }\end{array}$ & Norfolk & 1 & SAUNDERS & Henry Kind & $\begin{array}{l}\text { J.M. Saunders \& Co. (Bancroft, p. 59) } \\
\text { Saunders \& Bradley (Bancroft, p. 309) }\end{array}$ \\
\hline & $4 / 14 / 27$ & $\begin{array}{l}\text { Schooner } \\
\text { James } \\
\text { Monroe }\end{array}$ & Norfolk & 1 & SAUNDERS & P. Chubb & $\begin{array}{l}\text { J.M. Saunders \& Co. (Bancroft, p. 59) } \\
\text { Saunders \& Bradley (Bancroft, p. 309) }\end{array}$ \\
\hline & $4 / 14 / 27$ & $\begin{array}{l}\text { Schooner } \\
\text { James } \\
\text { Monroe }\end{array}$ & Norfolk & 5 & SAUNDERS & $\begin{array}{l}\text { Geo. F. } \\
\text { Skipworth }\end{array}$ & $\begin{array}{l}\text { J.M. Saunders \& Co. (Bancroft, p. 59) } \\
\text { Saunders \& Bradley (Bancroft, p. 309) }\end{array}$ \\
\hline & $4 / 14 / 27$ & $\begin{array}{l}\text { Schooner } \\
\text { James } \\
\text { Monroe }\end{array}$ & Norfolk & 6 & SAUNDERS & $\begin{array}{l}\text { R. D. Shiphan \& } \\
\text { Co. }\end{array}$ & $\begin{array}{l}\text { J.M. Saunders \& Co. (Bancroft, p. 59) } \\
\text { Saunders \& Bradley (Bancroft, p. 309) }\end{array}$ \\
\hline
\end{tabular}


Table A2

Shippers classified as traders by Steckel and Ziebarth

Shippers matched with slave traders who were identified in secondary sources

\begin{tabular}{|c|c|c|c|c|c|c|c|}
\hline 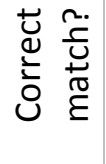 & Date & Ship & Port & slaves & $\begin{array}{c}\text { Name of } \\
\text { Shipper } \\
\text { (from Steckel) }\end{array}$ & $\begin{array}{l}\text { Name of Owner } \\
\text { (from manifest) }\end{array}$ & Name(s) of "Matched" Trader(s) \\
\hline & $4 / 14 / 27$ & $\begin{array}{l}\text { Schooner } \\
\text { James } \\
\text { Monroe }\end{array}$ & Norfolk & 24 & SAUNDERS & George Denton & $\begin{array}{l}\text { J.M. Saunders \& Co. (Bancroft, p. 59) } \\
\text { Saunders \& Bradley (Bancroft, p. 309) }\end{array}$ \\
\hline & $2 / 3 / 47$ & $\begin{array}{l}\text { Steamship } \\
\text { Galveston }\end{array}$ & Galveston & 19 & SMITH & G. Smith & $\begin{array}{l}\text { Thomas J. Smith (Charleston City Gazette Date: 01-26- } \\
\text { 1826) } \\
\text { Samuel Smith (Charleston City Gazette Date: 12-06-1826) } \\
\text { G. A. Smith (Macon Weekly Telegraph Date: 03-06-1834) }\end{array}$ \\
\hline & $12 / 5 / 47$ & $\begin{array}{l}\text { Steamship } \\
\text { Palmetto }\end{array}$ & Galveston & 11 & SMITH & $\begin{array}{l}\text { Jermiah Smith } \\
\text { (Galveston) }\end{array}$ & $\begin{array}{l}\text { Thomas J. Smith (Charleston City Gazette Date: 01-26- } \\
\text { 1826) } \\
\text { Samuel Smith (Charleston City Gazette Date: 12-06-1826) } \\
\text { G. A. Smith (Macon Weekly Telegraph Date: 03-06-1834) }\end{array}$ \\
\hline & $1 / 23 / 47$ & $\begin{array}{l}\text { Steamer } \\
\text { Palmetto }\end{array}$ & Galveston & 22 & SMITH & $\begin{array}{l}\text { J. Smith } \\
\text { (captain of } \\
\text { ship) }\end{array}$ & $\begin{array}{l}\text { Thomas J. Smith (Charleston City Gazette Date: 01-26- } \\
\text { 1826) } \\
\text { Samuel Smith (Charleston City Gazette Date: 12-06-1826) } \\
\text { G. A. Smith (Macon Weekly Telegraph Date: 03-06-1834) }\end{array}$ \\
\hline & $1 / 6 / 53$ & $\begin{array}{l}\text { Schooner } \\
\text { George } \\
\text { Lincoln }\end{array}$ & St. Marks & 11 & TAYLOR & $\begin{array}{l}\text { W. N. Taylor } \\
\text { (Florida) }\end{array}$ & $\begin{array}{l}\text { Samuel Taylor (Richmond Enquirer; Date: 01-05-1836) } \\
\text { R.A. Taylor (Charleston City Gazette; Date: 06-12-1823) }\end{array}$ \\
\hline & $1 / 6 / 53$ & $\begin{array}{l}\text { Schooner } \\
\text { George } \\
\text { Lincoln }\end{array}$ & St. Marks & 22 & TAYLOR & W. N. Taylor & $\begin{array}{l}\text { Samuel Taylor (Richmond Enquirer; Date: 01-05-1836) } \\
\text { R.A. Taylor (Charleston City Gazette; Date: 06-12-1823) }\end{array}$ \\
\hline & $6 / 18 / 47$ & $\begin{array}{l}\text { Schooner } \\
\text { George Ross }\end{array}$ & Baltimore & 4 & WILSON & $\begin{array}{l}\text { Thomas C. } \\
\text { Wilson } \\
\text { (Baltimore) }\end{array}$ & Jonathan M. Wilson, (Bancroft p. 122, 315). \\
\hline
\end{tabular}


